Syntax Literate : Jurnal Ilmiah Indonesia p-ISSN: 2541-0849

e-ISSN : 2548-1398

Vol. 5, No. 1 Januari 2020

\title{
GAMBARAN KARAKTERISTIK IBU BERSALIN DENGAN LETAK SUNGSANG DI RS KESDAM JAYA TAHUN 2018
}

\section{Siti Nurdiyana}

Sekolah Tinggi Ilmu Kesehatan (STIKes) Cirebon

Email: dian.aldiza@gmail.com

\begin{abstract}
Abstrak
Tujuan dari peneitian ini yaitu untuk mengetahui gambaran karakteristik Ibu Bersalin dengan Letak Sungsang di RS Kesdam Jaya tahun 2018. Deskriptif retrospektif yang dijadikan desain dalam penelitian ini. Pada penelitian ini menggambarkan tentang karakteristik Persalinan Sungsang di RS Kesdam Jaya Cijantung Jakarta Timur tahun 2018. Hasil penelitian pada 35 responden tentang karakteristik persalinan sungsang berdasarkan berat badan lahir yang paling tinggi adalah berat badan lahir normal (2500-4000 gram) sebanyak 32 responden (91\%) dan yang paling rendah adalah berat badan lahir rendah $(<2500)$ sejumlah 1 responden (3\%). Diketahui bahwa dari 35 responden mayoritas terjadinya persalinan letak sungsang adalah pada ibu bersalin dengan usia reproduksi sehat sebanyak 28 responden (80\%), sedangkan terendah pada usia reproduksi tisak sehat. Ibu bersalin dengan letak sungsang di RS Kesdam Jaya, mayoritas usia reproduksi sehat. Hal ini tidak sesuai dengan penelitian sumiati (2015) bahwa Usia > 35 tahun dapat menjadi faktor risiko persalinan sungsang. Hal ini kemungkinan berhubungan dengan mulai terjadinya regenerasi sel-sel tubuh terutama endometrium akibat usia biologis jaringan dan adanya penyakit yang dapat menimbulkan kelainan letak. Sedangkan Persalinan sungsang yang terjadi pada usia $<20$ tahun dipengaruhi oleh bentuk anatomi panggul ibu yang sempit dan kematangan organ reproduksinya.
\end{abstract}

Kata kunci: Karakteristik, Ibu Hamil, Ibu Bersalin

\section{Pendahuluan}

Diketahui bahwa tingkat kehamilan didunia mencapai 160 ibu hamil per tahun. Sebagian besar kehamilan ini berlangsung aman. Namun, komplikasi yang mengancam jiwa ibu tercatat sepertiga dari penderita komplikasi berat. Kondisi ini mengakibatkan kematian pada ibu untuk setiap tahunnya. Diperkirakan 90\% dialami oleh negara Asia dan Afrika, $1 \%$ dinegara maju dan $10 \%$ terjadi pada negara berkembang lainnya. Dinegara maju terjadi resiko kematian kurang dari 1 dalam 6000 sedangkan 1 dalam 10 terjadi dinegara berkembang (Geri Morgan: 2009) (Bardja, 2017).

Indikator yang paling peka dalam keberhasilan program kesehatan ibu dan anak yaitu angka kematian perinatal dan ibu bersalin, keadaan ini disebabkan oleh terjadinya malpresentasi termasuk diantaranya kelainan presentasi bokong, kejadian hipoksia dan trauma lahir (Jaworski et al., 2014). 
Pada presentasi bokong, baik ibu dan janin mengalami peningkatan risiko yang besar dibandingkan dengan presentasi kepala. Sedangkan persalinan letak sungsang dengan prematuritas memiliki morbiditas dan mortalitas lebih tinggi (Putra, 2015).

Dalam seluruh persalinan terjadi 3-4\% letak sungsang. Kejadian presentasi bokong berkisar antara 25-30\% ketika umur kehamilan 28 minggu dan presentasi kepala terjadi pada usia kehamilan 34 minggu (Insani, 2018).

Di Indonesia angka kejadian letak sungsang sekitar 3-5\% dari seluruh persalinan tunggal. Insiden persalinan letak sungsang meningkat pada kehamilan ganda.: 25\% pada gemelli janin pertama dan 50\% pada gemelli janin kedua (Nugrahantoro et al., 2017). Beberapa angka kejadian letak sungsang yang tercatat di Rumah Sakit Hasan Sadikin Bandung 4,6\%, Rumah Sakit dr Pirngadi Medan 4,4\% dan Rumah Sakit Umum Pusat dr. Kariadi Semarang 7,6\%. Di RSUD dr. R Koesma Tuban tercatat pada tahun 2014 ditemukan 98 kasus persalinan letak sungsang dari 987 persalinan (Jain, 2018).

Data yang diperoleh dari di RS Kesdam Jaya Cijantung Jakarta Timur pada tahun 2015 ditemukan sebanyak $22(5,47 \%)$ persalinan letak sungsang dari 402 persalinan, tahun 2016 sebanyak 18 (4,53\%) persalinan letak sungsang dari 397 persalinan dan tahun 2017 sejumlah 35 (7,67\%) persalinan letak sungsang dari 456 persalinan.

Kehamilan sungsang dapat disebabkan oleh banyak hal, antara lain: multiparitas, prematuritas, kehamilan ganda, hidramnion, hidrosefalus, anensefalus, plasenta previa, panggul sempit, kelainan uteri dan kelainan bentuk uterus, implantasi plalsenta di kornu fundus uteri (Fitriani \& Maulana, 2016).

Persalinan dengan letak sungsang dapat mengakibatkan kegawatan pada janin seperti keracunan air ketuban dan asfiksia, sedangkan pada ibu kemungkinan dapat terjadi robekan jalan lahir dan terjadinya partus lama sehingga dapat terjadi infeksi. Persalinan dengan letak sungsang dapat dilakukan per-vaginam apabila pasien bukan merupakan primigravida tua, nilai sosial janin tinggi (high social value baby), riwayat persalinan tidak buruk (bad obstetric history), janin tidak besar (tidak lebih dari 3,5 kg), tidak adanya kesempitan panggul dan tidak prematuritas (Utami, 2010).

Secara global $80 \%$ kematian ibu tergolong pada kematian ibu langsung. Pola penyebab langsung dimana-mana sama, yaitu perdarahan $28 \%$, eklamsia $24 \%$, infeksi $11 \%$, partus lama 5\%, dan abortus 5\%. Faktor yang berperan pada komplikasi persalinan yang menyebabkan kematian ibu salah satunya adalah kelainan letak (sungsang) (Setyaningsih, n.d.) Sedangkan penyebab kematian bayi adalah asfiksia trauma kelahiran, infeksi, prematuritas, kelainan bawaan (Prawirohardjo, 2014)

Dalam menurunkan Angka Kematian Ibu (AKI) diperlukan strategi yang efektif yaitu meningkatkan upaya kesehatan. Upaya kesehatan yang dapat diberikan adalah dengan asuhan persalinan normal dengan paradigma baru yaitu dari sikap menunggu dan menangani komplikasi menjadi mencegah komplikasi yang mungkin terjadi. Hal tersebut dapat diwujudkan dengan mendekatkan pelayanan kebidanan kepada setiap ibu yang membutuhkannya (Luthviatin, 2012). 
Penempatan bidan didesa maupun kota haruslah adil dan merata. Upaya ini diharapkan dapat mengurangi kesenjangan di daerah-daerah yang diinginkan. Upaya tersebut harus bersifat non-deskriminatif, sehingga setiap ibu yang membutuhkan pertolongan bidan wajib memperoleh pelayanan tersebut. Pelayanan yang diberikan bidan harus berkualitas dan terjamin keamanannya, efektif dan pembayaran yang terjangkau oleh setiap ibu hamil.

Adapun kompetensi, integritas dan objektifitas bidan menjadi sangat penting dalam memberikan pelayanan kepada ibu hamil. Tidak hanya itu, kerja teamwork menjadi komponen yang harus tetap dibangun demi ketepatan dan kecepatan dalam persalinan dan tidak adanya kesalahan. Jadi, pemerintah harus meningkatkan kuantitas dan kualitas dari bidan maupun tim yang akan membantu bidan dalam persalinan baik di perkotaan maupun di pedesaan (Luthviatin, 2012)

Peran seorang bidan adalah mendeteksi secara dini kehamilan dengan letak sungsang dan segera merujuk apabila ada kegawatan dalam kehamilan ataupun persalinannya. Persalinan dengan letak sungsang apabila tidak ditangani secara benar hal ini akan dapat mengakibatkan angka morbiditas dan mortalitas ibu dan bayi meningkat dan juga akan meningkatkan AKI dan AKB di Indonesia (Utami, 2010).

\section{Metode Penelitian}

Desain penelitian yang digunakan adalah deskriptif retrospektif. Desain penelitian ini memiliki tujuan utama yaitu untuk membuat gambaran atau deskripsi tentang suatu keadaan secara objektif dengan melihat ke belakang (Ainy, Khoiri, \& Herawati, 2015). Pada penelitian ini menggambarkan tentang karakteristik Persalinan Sungsang di RS Kesdam Jaya Cijantung Jakarta Timur tahun 2018.

\section{Hasil Dan pembahasan}

Dari hasil penelitian yang dilakukan oleh peneliti pada 35 responden tentang karakteristik persalinan sungsang berdasarkan berat badan lahir yang paling tinggi adalah berat badan lahir normal (2500-4000 gram) sebanyak 32 responden (91\%) dan yang paling rendah adalah berat badan lahir rendah $(<2500)$ sejumlah 1 responden $(3 \%)$.

\section{Karakteristik Ibu Bersalin dengan Letak Sungsang Berdasarkan Usia Ibu}

Berdasarkan data yang diperoleh dapat diketahui bahwa dari 35 responden mayoritas terjadinya persalinan letak sungsang adalah pada ibu bersalin dengan usia reproduksi sehat sebanyak 28 responden $(80 \%)$, sedangkan terendah pada usia reproduksi tisak sehat.

Ibu bersalin dengan letak sungsang di RS Kesdam Jaya, mayoritas usia reproduksi sehat. Hal ini tidak sesuai dengan penelitian sumiati (2015) bahwa Usia $>35$ tahun dapat menjadi faktor risiko persalinan sungsang. Hal ini kemungkinan berhubungan dengan mulai terjadinya regenerasi sel-sel tubuh terutama endometrium akibat usia biologis jaringan dan adanya penyakit yang dapat menimbulkan kelainan letak. Sedangkan Persalinan sungsang yang terjadi pada 
usia $<20$ tahun dipengaruhi oleh bentuk anatomi panggul ibu yang sempit dan kematangan organ reproduksinya.

\section{Karakteristik Ibu Bersalin dengan Letak Sungsang Berdasarkan Paritas}

Berdasarkan distribusi menurut paritas didapatkan jumlah tertinggi pada multipara yaitu sebanyak 19 responden (52\%), kemudian pada primipara sebanyak 14 responden $(40 \%)$ dan yang terendah pada grandemultipara yaitu 2 responden (8\%). Penelitian ini sejalan dengan penelitian (Putra, 2015) dengan hasil yang didapatkan angka kejadian tertinggi pada persalinan letak sungsang adalah multipara yaitu sebesar 98 orang dari total sampel $152(64,5 \%)$.

Hal ini sesuai dengan teori hubungan paritas dengan letak sungsang yaitu dimana ibu telah melahirkan banyak anak sehingga rahim menjadi elastis dan memicu janin berputar hingga minggu ke-37 hingga akhirnya terjadi letak sungsang. Perut gantung terjadi pada grandemultipara, hal ini disebabkan oleh regangan uterus yang terus-menerus karena kehamilan dan longgarnya ligamentum yang memfiksasi uterus, sehingga uterus menjadi jatuh ke depan. Kondisi perut gantung berdampak pada ibu hamil, dimana posisi uterus yang menggantung kedepan sehingga janin tidak dapat menekan, rapat dan berhubungan langsung dengan segmen bawah rahim. Akhirnya janin dapat mengalami kelainan letak, seperti letak sungsang (Sunarto et al., 2011).

3. Karakteristik Ibu Bersalin dengan Letak Sungsang Berdasarkan Usia Kehamilan

Berdasarkan distribusi menurut usia kehamilan didapatkan jumlah tertinggi persalinan letak sungsang pada usia kehamilan aterm (37-42 minggu) yaitu sebanyak 30 responden (86\%).

Penelitian ini tidak sejalan dengan teori yang menyatakan bahwa kejadian letak sungsang banyak terjadi pada usia kehamilan kurang bulan dan pada usia kehamilan cukup bulan biasanya ialah letak kepala. Hal ini juga ditemukan pada penelitian sebelumnya yang dilakukan Dengah (2011), ditemukan kasus tertinggi pada usia kehamilan 37-41 minggu yaitu sebanyak 74 orang $(85,05 \%)$.

4. Karakteristik Ibu Bersalin dengan Letak Sungsang Berdasarkan Jenis Persalinan

Berdasarkan distribusi menurut jenis persalinan didapatkan bahwa semua persalinan letak sungsang dilakukan secara perabdominal (operasi sesar) yaitu sebanyak 35 responden (100\%).

Semua ibu bersalin dengan letak sungsang di RS Kesdam Jaya, dilakukan persalinan secara perabdominal (secsio caesarea). Hal ini sesuai dengan teori (Prawirohardjo, 2014) bahwa indikasi dilakukannya tindakan seksio antara lain ibu yang primi tua, bekas seksio sesaria, ada indikasi janin untuk mengakhiri persalinan (hipertensi, KPD), dan curiga panggul sempit.

Hasil serupa juga dilaporkan oleh penelitian sebelumnya yang dilakukan Putra, dkk (2016) bahwa yang mendapatkan jenis persalinan perabdominal pada persalinan letak sungsang sebanyak 119 kasus (78,3\%). 


\section{Karakteristik Ibu Bersalin dengan Letak Sungsang Berdasarkan Berat Badan Lahir}

Terjadinya persalinan sungsang biasanya disebabkan oleh berat badan lahir bayi. Dimana yang sering terjadi persalinan sungsang adalah bayi dengan berat lahir rendah, yaitu berat lahir < 2500 gram. Hal ini dapat disebabkan oleh bentuk rahim relative kurang lonjong, air ketuban masih banyak dan kepala anak relative besar (Dalminarti, 2015).

Berdasarkan distribusi menurut berat badan lahir didapatkan jumlah tertinggi pada berat badan lahir normal (2500 - 4000 gram) yaitu sebanyak 32 responden $(91 \%)$, diikuti pada berat badan lahir lebih (>4000 gram) sebanyak 2 responden $(6 \%)$, sedangkan yang terendah pada berat badan lahir rendah $(<2500$ gram) yaitu 1 responden (3\%).

Penelitian ini sejalan dengan penelitan Dengah (2011), didapatkan jumlah tertinggi berat badan lahir pada persalinan letak sungsang adalah pada berat badan lahir 2500 - 3000 g yaitu sebanyak 37 kasus $(42,52 \%)$.

\section{Kesimpulan}

Berdasarkan hasil penelitian dan pembahasan mengenai gambaran karakteristik ibu bersalin dengan letak sungsang di RS Kesdam Jaya Tahun 2018, dapat disimpulkan sebagai berikut:

a. Karakteristik ibu bersalin dengan letak sungsang berdasarkan usia sebagian besar responden adalah usia reproduksi sehat sebanyak 28 responden (80\%).

b. Karakteristik ibu bersalin dengan letak sungsang berdasarkan paritas sebagian besar adalah multipara sebanyak 19 responden $(52 \%)$.

c. Karakteristik ibu bersalin dengan letak sungsang berdasarkan usia kehamilan sebagian besar terjadi pada usia kehamilan aterm (37-42 minggu) sebanyak 30 responden $(86 \%)$.

d. Karakteristik ibu bersalin dengan letak sungsang berdasarkan jenis persalinan, semua persalinan dilakukan secara perabdominal (operasi SC) sebanyak 35 responden $(100 \%)$.

e. Karakteristik ibu bersalin dengan letak sungsang berdasarkan Berat Badan Lahir (BBL) sebagian besar terjadi pada berat badan lahir normal (2500 - 4000 gram) sebanyak 32 responden $(91 \%)$. 


\section{BIBLIOGRAFI}

Ainy, Q., Khoiri, A., \& Herawati, Y. T. (2015). Analisis Faktor yang Berhubungan dengan Kinerja Bidan dalam Pelayanan Antenatal Care di Wilayah Puskesmas Kabupaten Jember Tahun 2015. diakses 29 Oktober 2017 [13.42]. Skripsi. Fakultas Kesehatan Masyarakat Universitas JEMBER.

Bardja, S. (2017). Faktor-Faktor Yang Mempengaruhi Terjadinya Hipertensi Dalam Kehamilan Pada Ibu Hamil Di Puskesmas Gunung Jati Tahun 2015. Syntax Literate; Jurnal Ilmiah Indonesia, 2(11), 151-161.

Fitriani, K., \& Maulana, M. (2016). Meningkatkan Kemampuan Pemahaman dan Pemecahan Masalah Matematis Siswa SD Kelas V Melalui Pendekatan Matematika Realistik. Mimbar Sekolah Dasar, 3(1), 40-52.

Insani, M. (2018). Manajemen Asuhan Kebidanan Intranatal pada $N y$ “ $E$ ” dengan Persalinan Sungsang di RSUD Syekh Yusuf Gowa Tanggal 04 September 2018. Universitas Islam Negeri Alauddin Makassar.

Jain, M. (2018). Contemporary urbanization as unregulated growth in India: The story of census towns. Cities, 73, 117-127.

Jaworski, E., Narayanan, A., Van Duyne, R., Shabbeer-Meyering, S., Iordanskiy, S., Saifuddin, M., ... Chung, M. (2014). Human T-lymphotropic virus type 1-infected cells secrete exosomes that contain Tax protein. Journal of Biological Chemistry, 289(32), 22284-22305.

Luthviatin, N. (2012). Dasar-Dasar Promosi Kesehatan \& Ilmu Perilaku.

Nugrahantoro, A., Miranda, A., Fiitriani, N., Stefanny, V. B., Husna, N. N., Maharani, B. C., ... Virlist, U. Y. (2017). Laporan Pelaksanaan Kuliah Kerja Nyata Reguler Universitas Ahmad Dahlan Periode LXI Tahun Akademik 2016/2017 Divisi XIII. C. 2 Di Dusun Banyu Urip, Kelurahan Jatimulyo, Kecamatan Dlingo, Kabupaten Bantul Provinsi Yogyakarta. Laporan Pelaksanaan Kuliah Kerja Nyata Reguler Universitas Ahmad Dahlan Periode Lxi Tahun Akademik 2016/2017 Divisi XIII. C. 2 Di Dusun Banyu Urip, Kelurahan Jatimulyo, Kecamatan Dlingo, Kabupaten Bantul Provinsi Yogyakarta.

Prawirohardjo, S. (2014). Ilmu Kebidanan Sarwono Prawirohardjo, Jakarta, Pt. Bina Pustaka Sarwono Prawirohardjo.

Putra, I. (2015). Putu Santika dkk. 2016. Pengaruh tingkat literasi keuangan, experienced regret, dan risk tolerance pada pemilihan jenis investasi. Journal of Business and Banking, 5(2).

Setyaningsih, I. I. N. (n.d.). Upaya Meningkatkan Kecerdasan Otak Melalui Permainan Ice Breaker Pada Kelompok B TK Tunas Rimba di Kecamatan Tembalang Kota Semarang Tahun Ajaran 2012/2013. 
Siti Nurdiyana

Sunarto, A., McColl, K. A., Crane, M. S. J., Sumiati, T., Hyatt, A. D., Barnes, A. C., \& Walker, P. J. (2011). Isolation and characterization of koi herpesvirus (KHV) from Indonesia: identification of a new genetic lineage. Journal of Fish Diseases, 34(2), 87-101.

Utami, C. W. (2010). Manajemen Ritel_Strategi dan Implementasi Operasional Bisnis Ritel Modern Di Indonesia. 2010-ISBN: 978-979-061-127-6-Salemba Empat. 